of them are not represented in print by serious studies. A welcome is therefore due to a new Olunyaneka-Portuguese Dictionary issued by the Missão da Huila (194r), as we are not aware of any previous vocabulary or dictionary of this language of Portuguese West Africa. It is based upon a manuscript left by the late Father Bonnefoux, and its present Editor pays tribute in the Introduction to the scrupulous exactitude of Father Bonnefoux's work and says that his excess of modesty might have withheld it still longer from publication. Scholars will welcome this addition to the mounting list of documents on Bantu languages and it should contribute notably to our knowledge of the languages of this area of Africa.

The manuscript has been revised and added to and includes the scientific names of the commoner flowers and animals of the region. Dialectal relationships and problems have evidently been considered and certain variants indicated.

\title{
Anthropos
}

ENGLISH anthropologists will all welcome the appearance of the I940-I volume of Anthropos (vol. xxxv-xxxvi, nos. I-3), published in Switzerland in July 1942, and still under the editorship of Pater Wilhelm Schmidt. In the shrinking world in which we live it is comforting to find a periodical that reviews learned journals from Germany to Japan, from Sweden to Switzerland, and from America to Belgium. The volume is produced, too, with its customary scholarship and presents an almost peace-time appearance.

There are three English articles in the volume-one by Earl W. Count on 'Red and Black', a study of the distribution of red and black in American Indian designs; a valuable account of 'Azania', the Greek geographers' name for the East African coast, by G. W. B. Huntingford; and a study of 'Bhagwān, the supreme deity of the Bhils', by Pater Koppers. Pater Matthias Hermanus contributes an interesting note on some of the peoples of Northeastern Tibet with beautiful photographs. Pater Albert Aufinger describes 'Siedlungsform und Häuserbau an der Rai-Küste Neuguineas'. English readers will be interested in Pater L. Molinaro's 'A ppunti circa gli Usi, Costumi e Idee religiose dei Lotuko dell' Uganda'. Felix Speiser has provided a long article on the distribution of fire tools in the South Seas, ' Über Feuerzeuge in der Südsee'. French anthropologists are represented by Pater Jérôme Adam's 'Nouvel extrait du Folk-lore du Haut-Ogooué and Jean Gabus' 'Les mouvements migratoires chez les Esquimaux-caribous'.

There is a full bibliography of works published since 1939, reviews, and notes.

\section{Linguistic Studies in French Equatorial Africa}

WeLCOME news of linguistic activity comes from French Equatorial Africa. Madame BaratPepper, of the Fighting French Forces, who attended a short course of lectures organized by the School of Oriental and African Studies and the Colonial Department of the Institute of Education in the winter of $1940-1$, went subsequently to do educational work in Brazzaville. She and her husband, who are both trained musicians, became interested, during their course in London, in linguistic problems and particularly in the study of tone. They had the great good fortune, when they arrived in Brazzaville, to find Monsieur Éboué, the Governor-General, ready to give them every encouragement. He himself is a keen linguist and in his book, Les Peuples de l'Oubangui, he made interesting suggestions about the correspondence between the tones of the Banda language and the drum-taps used for sending messages. He has recently arranged for $M$. and Mme Pepper to do a linguistic tour including both Banda-Linda country and the Chad area. For Banda they were to get the tones of the words in Monsieur Éboué's Vocabulaire Francais-Banda by listening to the tapping of these words on the linga-the percussion instrument used for sending messages. 